\title{
Internet Valuations And Economic Sustainability
}

\author{
Dr. Chris Rose, Walden University, USA
}

\begin{abstract}
AOL bought the social networking site Bebo for $\$ 850$ million in 2008 but sold it for pennies two years later. Recently the former premier social networking site, MySpace, reduced their staff by $47 \%$ and restructured again amid mounting losses. These are good indicators that economic sustainability on the Internet, especially among social networking sites is not guaranteed. The recent massive $\$ 80$ billion valuation of the social networking site Facebook should therefore be looked at with caution.
\end{abstract}

Keywords: Facebook, LinkedIn, Twitter, Foursquare, My Space

\section{INTRODUCTION}

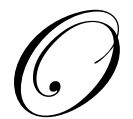

ne out of every 13 people in the world and three out of four Americans is on Facebook and one out of 26 signs into Facebook daily (O'Dell, 2011). With more than 500 million users (Chmielewski and Guynn, 2011), Facebook has now surpassed Google and is now the most popular site on the Internet (Mui and Whorisky, 2011). Facebook was recently valued at over $\$ 80$ billion (if the secondary markets are included) and also just received another infusion of cash of $\$ 1.5$ billion from Goldman, Sachs (Quain, 2011). However, soaring Internet popularity and extremely high expectations and valuations are nothing new as this is a recurring theme on the Internet.

Facebook is now the most popular social media site but it is far from being the only one. Social media can be described as a website that not only provides information, but interacts with you while it is giving you that information. Examples would include MySpace, Facebook, LinkedIn, Foursquare and Twitter or any other site that allows users to share personal information. In a traditional web site, the content is delivered to the end user but they are not allowed to update or participate in the creation of the content on the web site but in social media, people are communicating, sharing, networking and interacting with others.

\section{NETWORK EXTERNALITIES}

Unlike physical networks, it is ubiquity that drives value in social networks. For example, there is only one physical copy of the painting the Mona Lisa, that makes it valuable since if there were a thousand of those paintings it would have very little value. In a digital network it is the complete opposite, since if there was only one of a certain piece of technology it would have little value, the value is derived from ubiquity and this is driven by strong network externalities.

A network externality arises from the concept that some goods and services are more valuable when more people consume or utilize that good or service and yet these goods and services have little or no value if they are used without a network (Katz \& Shapiro, 1995). Typical examples of these would be telephones and fax machines as people who own these products would form a network to be able to exchange information and provide a way for people to communicate with each other. The more people who have telephones the more valuable this network becomes. Electronic networks such as communication and information networks are said to exhibit positive production and consumption externalities since the value of the good that is a part of the network increases with the number of units sold since each unit complements each other that in turn will increase the value of the component (Rose and Gordon, 2003). 
It is network externalities that drives the popularity of social networks and Mark Zuckerberg, the CEO of Facebook, calls his mapping of network externalities their "interest graph" and believes that this is the key to their success. In fact, Facebook wants to capitalize on this graph by "renting their graph to websites through Facebook Connect, which, he says, is exceptionally powerful and in turn may lead to their successfully replacing core messaging services" (Empson, 2011).

Some historical perspective is necessary whenever the popularity and valuation of Facebook is examined since previously, many other companies have also been popular but have quickly faded to obscurity.

\section{COMPUSERVE}

The original CompuServe service, first offered in 1979, was shut down in 2009 by its current owner, AOL. CompuServe was the first major Internet service, but it had seen the number of users decrease in recent years. At its height, CompuServe boasted about having over half a million users simultaneously on line and considering when CompuServe was at its peak, that was a significant percentage of total Internet users."Many innovations we now take for granted, from online travel, online shopping, online stock quotations, and global weather forecasts, just to name a few, were standard fare on CompuServe in the 1980s" (Doctorow, 2009). AOL was the up and coming competitor to CompuServe and in a complex business deal, WorldCom acquired CompuServe and sold to AOL, therefore AOL would become the owners of CompuServe. AOL eventually became the new premier web site and ended up acquiring CompuServe's online services in 1997, with the intention of keeping CompuServe online and operational as a separate service from AOL. However, AOL's online services, which were based on dial-up connections, became increasingly irrelevant in a modern broadband world, therefore Time Warner's decided to spin off AOL (Cheng, 2009).

\section{AOL - TIME WARNER}

It was just a decade ago that America Online merged with Time Warner in a deal valued at a massive $\$ 350$ billion, the largest merger in the history of American business. AOL's lofty stock price made it worth twice as much as Time-Warner although it had less than half the cash flow (Arrango, 2011). AOL was the Google of its time, it was how America got to the Internet. Almost every day those AOL CDs would arrive in the mail, they were given away freely in many stores, they were everywhere, and Steve Case, the CEO of AOL was as highly touted as Mark Zuckerberg, the CEO of Facebook is today, he could do no wrong. That deal is today taught in business schools around the world as the worst deal in American business history. Ted Turner, who became Vice-Chairman after the merger and was the largest stockholder, lost 80 percent of his net worth or about $\$ 8$ billion, and subsequently lost his job (Arrango, 2011).

\section{AOL - BEBO}

AOL announced in 2008, that they had acquired social networking service Bebo for $\$ 850$ million in cash. Bebo had 100 employees operating in offices in the UK, San Francisco and Austin, TX, and was the third-largest social networking web site in the U.S. behind MySpace and Facebook. "For February 2008, Compete shows 3.5 million U.S. visitors to Bebo, 28 million to Facebook and 65 million to MySpace." (Stern, 2008). The price tag of $\$ 850$ million was much higher than the $\$ 580$ million that News Corp. spent on MySpace parent company Intermix in 2005. Last year, with Facebook the clear winner in social-networking, AOL sold Bebo for pennies to a privateequity firm (McCarthy, 2011). The price was not disclosed, but some reports peg it at $\$ 10$ million or less, but other anonymous sources describe the price as an "exceptionally uninspiring number." Ironically, Steve Case, the former CEO of AOL who engineered the Time Warner deal, even stated that "AOL buying Bebo for $\$ 850$ million and then selling two years later for $\$ 10$ million doesn't seem like a winning strategy (Helft, 2010).

\section{AOL - HUFFINFTON POST}

But AOL still has not learned from past mistakes. Recently AOL acquired the Huffington Post, a leftleaning news web site for $\$ 315$ million, a deal that many people are questioning. Despite all positive spin by the CEOs about synergy, it is possible that once again these are two companies hoping that by merging, the other 
company will solve its own problems. Perhaps it is also about the money and the investors just need to cash out since the numbers for the Huffington Post weren't looking good enough for an IPO so maybe, it is thought, Arianna Huffington will just spend a few years at AOL and then move on. "This means that, in 2011, Huffington Post will be playing the same role in relation to AOL that AOL played in relation to Time Warner back in 2000: selling itself at the top of a market bubble, pocketing the profit from a sale that couldn't be earned from customers, and leaving a bigger, older company with all the headaches" (Rosenberg, 2011).

\section{MYSPACE}

In 2005, Rupert Murdoch, the head of media giant News Corp., was extremely confident when his firm's MySpace was the reigning premier social networking site. He claimed it was "not just looking up friends," as rival Facebook was doing (Chmielewski and Guynn, 2011). News Corp paid $\$ 580$ million in cash to acquire Intermix Media Inc., the company that owned MySpace.com, a Web site that was enjoying unprecedented popularity with young audiences. "MySpace.com is a youth-oriented music and "social networking" site that has grown to more than 16 million monthly users. Its members spend hours on the site, exploring areas devoted to personal classifieds, music, blogs, video games and chat rooms" (Siklos, 2005).

By 2011, MySpace CEO Mike Jones announced a "significant organizational restructuring that will result in a 47 percent staff reduction across all divisions globally and impact about 500 employees". Although MySpace was formerly the leading social-networking web site, it rapidly lost ground to Facebook then it underwent a major redesign, whereby instead of attempting to be a social media site with general appeal it instead focused on pop culture media-sharing for young users (McCarthy, 2011). News Corp. is considering a possible spinoff or sale of MySpace, since News Corp. is unwilling to continue bear continuing losses, which amounted to just under $\$ 100$ million in the year ended in June (Fixmer and Rabil, 2011).

Although MySpace was struggling to reinvent itself its traffic continued to plunge. Comscore, an Internet metrics site, says MySpace had 80 million worldwide unique visitors in December 2010, which is down from 90 million in October before they redesigned the site to focus on entertainment and in fact, one year ago they had 120 million unique visitors. Surprisingly, another, smaller, social network has apparently found a way to be profitable. "San Francisco based Tagged logged revenues of over $\$ 30$ million in 2010 and are profitable with a staff of 50... they've been profitable for the last three years. And now they're hiring." Tagged gave an across the board 10\% raise to every full time employee and intends to double staff from 50 to 100 employees. Tagged is focusing on something Facebook has ignored for the last several years, by letting users actually meet other users on the site (Arringon, 2011).

\section{FАCЕВOOK}

Facebook "has a stratospheric valuation, an Oscar-nominated movie about it, 600 million fans, and its CEO just appeared on Saturday Night Live". But it is beginning to feel like Facebook is beginning to sag under its own mighty weight and is suffering from the same type of Netscape-era hype. In fact, Facebook recently received an injection of $\$ 1.5$ billion injection of capital from Goldman, Sachs and others, which now means its estimated market value of approximately $\$ 50$ billion, or if the secondary market is counted, over $\$ 82$ billion, now makes it more valuable than Amazon.com (Quain, 2011).

But it seems like Facebook's days may already be numbered because although Facebook started out as a simple, fun place to digitally play and have fun, it has quickly become a complex maize of lurking dangers, posing threats to our personal security and safety. Facebook's greatest problem is that it's too big to easily manage any more. Once you accumulate a certain number of Facebook friends, you can't be sure who will see what you post and you can't know what they're going to do with it. Complexity is the enemy of social networking, and complexity is killing Facebook. (Quain, 2011)

Facebook knows it has a problem and already many are sensing a "what's the next big thing?" vibe on the site, so Facebook is trying to introduce e-mail and it is working closely with the Internet calling service, Skype, perhaps making the same mistakes as eBay. Facebook has even tried to duplicate location-based services like 
Foursquare but none of these initiatives has been particularly successful. They can't use all that valuable customer information that it has accumulated to make money, because security experts will just see that as intrusion into our personal privacy. On the Internet, brand loyalty doesn't count for much. Prodigy, Pointcast, AOL and Yahoo "were all darlings of the digital age, too. FB friends can be fickle, and if people from my list of truly cool FB friends join another site, I'll probably go too. After all, nobody wants to miss the next big thing" (Quain, 2011).

Also confirming that the social networking hype and market has reached its peak, LinkedIn is also rapidly moving toward its own IPO, and it intends to do so before Facebook gets there and spoils the IPO process for everyone else. Unfortunately, people value these companies as if they will always be our means for identifying ourselves but social media, just like any other social gathering, nightclub or party is temporary. It is the people that matter and not the venue, so just like the party scene when "the trend leaders of one social niche or another decide the place everyone is socializing has lost its luster or, more important, its exclusivity, they move on to the next one, taking their followers with them"(Rushkoff, 2011).

\section{CONCLUSION}

Facebook's successor (whoever that might be) will no doubt provide an easy migration utility through which you can bring all your so-called friends with you.

We will move on, just as we did from the chat rooms of AOL, without even looking back. So it's not that MySpace lost and Facebook won. It's that MySpace won first, and Facebook won next. They'll go down in the same order. The longer the company can maintain the illusion of great profits without alienating its user base, the longer they can delay the inevitable decline. But given that Facebook has already begun cashing in its chips, that moment has quite likely arrived (Rushkoff, 2011).

Remember, on the Internet, for those who don't have a sustainable business model cashing out is the name of the game; therefore we are witnessing the beginning of the end of Facebook. These aren't the symptoms of a company that is winning, but one that is cashing out. The object of the game, for any one of these ultimately temporary social networks, is to create the illusion that yours is different, permanent, invincible and too big to fail, and Facebook has created that illusion. If you were there for CompuServe, AOL, Tripod, Friendster, Orkut, MySpace or LinkedIn, you would understand (Rushkoff, 2011).

\section{REFERENCES}

1. Arrango, T. 2011, January 10. New York Times. How the AOL-Time Warner Merger Went so Wrong. Retrieved 2/4/2011 from http://www.nytimes.com/2010/01/11/business/media/11 merger.html?pagewanted=1\&_r=1

2. Arringon, M. (2011, January 27) TechCrunch. As MySpace Implodes, Tagged Doubles Staff And Gives Everyone A Raise. retrieved 2/11/2011 from http://techcrunch.com/2011/01/27/as-myspace-implodestagged-doubles-staff-and-gives-everyone-a-raise/

3. Cheng, J. (2009, July 6). ArsTechnica. Goodbye, CompuServe! (We thought you already died). Retrieved 2/9/2011 from http://arstechnica.com/telecom/news/2009/07/goodbye-compuserve-we-thought-you-hadalready-died.ars

4. Chmielewski, D and Guynn, J. (2011, January 12). LAtimes. MySpace layoffs are part of broad restructuring. Retrieved 2/26/2011 from http://www.latimes.com/business/la-fi-ct-myspace20110112,0,3960758.story

5. Doctorow, C. (2009, July 3). BoingBoing. CompuServe shuts down. Retrieved 2/10/2011 from http://boingboing.net/2009/07/03/compuserve-shuts-dow.html

6. $\quad$ Empson, R. (2011, February 17) TechCrunch. Levchin and Gurley Say That Next Big Company Will Capture The Interest Graph. Retrieved 2/23/2011 from http://techcrunch.com/2011/02/17/levchin-andgurley-say-that-next-big-company-will-capture-the-interest-graph/

7. Fixner, A and Rabil, S. (2011, January, 12) Bloomberg. MySpace Sale, Merger or Spinoff Being Weighed by News Corp., Official Says. Retrieved 2/18/2011 from http://www.bloomberg.com/news/2011-01$12 /$ myspace-sale-merger-or-spinoff-being-weighed-by-news-corp-official-says.html 
8. Helft, M. (2010, June 17). The New York Times. AOL Unloads Social Networking Site Bebo. Retrieved 2/8/2011 from http://bits.blogs.nytimes.com/2010/06/17/aol-unloads-social-networking-site-bebo/

9. Katz M. and Shapiro C. (1995, June) Network Externalities, Competition and Compatibility. American Economic Review.

10. McCarthy, C. (2011, January, 11) CNet news. Should MySpace just die already? Retrieved 2/14/2011 from http://news.cnet.com/8301-13577_3-20028201-36.html?tag=topStories1

11. Mui, Y. and Whoriskey, P. (2010, December 1) Washington Post. Facebook cements No. 1 status. retrieved 2/6/2011 from http://www.washingtonpost.com/wpdyn/content/article/2010/12/30/AR2010123004625.html

12. O'Dell, J. (2011, January 13) CNN.com. Are we too obsessed with Facebook? Retrieved 2/17/2011 from http://www.cnn.com/2011/TECH/social.media/01/13/too.obsessed.facebook.mashable/index.html?hpt=Sbi $\underline{\mathrm{n}}$

13. Quain, J. (2011, February 1) FoxNews. Is the Facebook Fad Ending? Retrieved 2/8/2011 from http://www.foxnews.com/scitech/2011/02/01/facebook-losing-focus/

14. Rose, C. and Gordon, J. (2003). Internet Security and the Tragedy of the Commons, International Business \& Economics Research Journal, Vol. 1, No. 2, pages $67-71$.

15. Rosenberg, S. (2011, February 7) Salon.com. Huffington Post/AOL: It's AOL/Time Warner all over again. Retrieved 2/22/2011 from http://www.salon.com/news/feature/2011/02/07/huffington_post_aol_deal_open2011

16. Rushkoff, D. (2011, January 7) CNN.com. Facebook hype will fade. Retrieved 2/14/2011 from http://edition.cnn.com/2011/OPINION/01/07/rushkoff.facebook.myspace/?hpt=Sbin

17. Silkos, R. (2005, July 7) The New York Times. News Corp. to Acquire Owner of MySpace.com. Retrieved 2/14/2011 from http://www.nytimes.com/2005/07/18/business/18cnd-newscorp.html

18. Stern, A. 2008, March 13. CenterNetworks. Bebo To AOL for $\$ 850$ Million http://www.centernetworks.com/aol-acquires-bebo-850-million 
NOTES 